\title{
Students' Peer Feedback in EFL Writing Class of English Study Program
}

\author{
William. Y Saptenno \\ williamsapwork@gmail.com \\ Postgraduate English Education Study Program, UNPATTI \\ Threesje R. Souisa \\ chocha72@yahoo.com \\ English Education Study Program, FKIP UNPATTI
}

\begin{abstract}
As a part of writing process, feedback in writing place as the significant role and peer feedback is one type of feedback in classroom activities. This study was intended to find out the facts and expectation on peer feedback in writing classroom. A classroom-based research was employed as the research design and the participants were the students in writing 2 and writing 4 courses. Furthermore, Classroom observation, in-depth interview and review of related documents were designed to collect the data. The findings revealed that the application of peer feedback was not properly applied; it was more focused on the surface areas (grammatical errors, spelling and error punctuation) and neglected to the content and organization of writings. It could happen because the students lack of trainings and unavailability of rubric and guidelines provided in the writing classroom activities. For that reason, the students didn't know the ways to provide meaningful and constructive feedback. They also have negative point of view about the peer feedback in writing courses. The students expected that providing writing rubric containing content and organization aspects precisely in giving feedback and guiding them step by step in taking and giving peer feedback should be considered by the lecturers for better improvement in the future.
\end{abstract}

Key Words: peer feedback, facts, expectations, classroom -based research.

\section{Introduction}

As part of the revising stage, giving feedback is widely practiced as a teaching writing activity and cannot be separated in the writing process. Writing needs feedback to make it becomes good writing (Iryanti, 2016), that is why receiving feedback is important in the writing activity itself. Moreover, Brookhart (as cited in Elashri, 2013) pointed that without providing appropriate feedback, students could not drive their focus on the weakness of their writings and felt hard to 


\section{Huele $e^{\text {(I) }}$}

Journal of Applied Linguistics,

Literature and Culture

reflect their own writing that should be improved. In general, students will receive sorts of feedback from other students and the teacher. However, in real classroom activity of the EFL context, the teacher seems the only main role in giving feedback for students' writing. The teacher will assess it by using an appropriate writing scoring rubric, give comments with some revision, and ask students to revise their work. From this process, it seems that students have spoon-fed and as result, they cannot learn from their mistakes and will have no real improvement in writing tasks.

To avoid students mistakes in writing tasks, the teacher can utilize peer review as a useful activity, where there is peer feedback included. Peer review can be defined as the way of two students' asses their written works and have some constructive critics to improve their writing (Riyani, 2009). This way transform into student-centered activity by assigning students to give feedback on their peer's writing. Students will work in pairs or groups and correct work by providing feedback on each other's text. In this activity, students will work collaboratively with their partners to provide feedback, so their writing will improve over time. Moreover, Bartles (2003) argued that when students study others' writings project and have comments about their writings, it can be called as peer feedback process, and they usually have some guided questions facilitated by the teacher. Providing peer feedback is not only beneficial for a receiver of the feedback in the writing process, but also it is useful for those that give feedback, as they have to be critical in analyzing other's writing. In line with this idea, Hyland (2004) explained that through peer feedback, students can gain some benefits such as improving their writing' drafts as well as developing understanding of good writing.

Despite its advantage of having peer feedback in the writing process, asking students to work in pairs and exchanging ideas has no guarantee that the activity will achieve its goals in helping students to improve in writing. Ferris (as cited in Riyani, 2009) said that some students may not welcome their partner's feedback because they may think of the capability of who will give them feedback and they are more reliant on the teacher's feedback. In resembling Ferris's idea, (Hanson, 2015) stated that students have a tendency to value teacher feedback higher than their peers. This might happen because students think that the teacher is far more superior to their friends in giving feedback and the teacher is the source of information and knowledge that the students still rely on and depend on. He also added some constraints like; lack of self-confidence, they are not able to give feedback that is substantial enough, and physiological aspect.

The researchers conducted a preliminary study in English Education Study Program by observing classroom writing activities and found that the students who provided the feedback on 
their peer's writing project mostly focused on the grammatical area, which means they were not focusing on the content, style, and organization of the text. Surely it was quite helpful but the needs of developing good writing are beyond the grammatical errors. This case was commonly happening through several times of the outlining and drafting process. There was another interesting case such as the students with higher achievement in writing, tend to be better in providing constructive feedback on other's writing than the students who have the lower in writing ability. In the writing process, students didn't have a clear picture about giving feedback and they were used to focused on grammatical errors and punctuation placement rather than the content and writing organization. In fact, some students considered feedback as a good source to improve their writing, they were more desired to receive feedback from the teacher.

Based on preliminary study above, the study is aimed at 1) describing the facts in giving and taking peer feedback in classroom writing activities at English Study Program, 2) finding out the students 'expectations of using peer feedback in classroom writing activities at English Study Program.

\section{Methods}

Descriptive Qualitative approach with a classroom-based research design was applied to conduct the study. Cooper, Barton \& TPR Group (2009) stated that 'classroom-based research is a study to find out the influence of interventions made in the classroom'. It usually researches about students 'knowledge, skills, and/or attitudes about the situation that they have in the process of teaching and learning. The procedures of classroom-based research containing planning and preparing, collecting data and analyzing data. In collecting data some instruments were applied such as classroom observation and in- depth interview.

\section{Research Site and Participant}

This study took place at the English Education Study Program at Pattimura University in writing 2 and writing 4 courses because at the time of conducting this study, there were only two classes of writing course that can be the research filed. The participants of this study were the students who have enrolled both classes. Furthermore, 4 selected participants for the in-depth interview were chosen based on the criteria such as their level of learning achievement and writing proficiency 


\section{Data Collection and Analysis}

In collecting the data, three instruments were created based on theory and it consisted of classroom observation checklist, in-depth interview and review documents. In analyzing the data, it is started form reducing data, displaying data, conclusion and verification.

\section{Findings}

\section{Classroom Observation}

The classroom observation has been conducted several times during the process of data collection from both writing 2 and writing 4 courses because the focused on this study was in writing skill, and those courses where be scheduled in the even semester. The purpose of conducting this observation was to gain the facts around the peer feedback process from both classes. The result of classroom observation presented below:

Table 1. Writing 2 course

\begin{tabular}{|c|c|c|c|c|}
\hline \multicolumn{5}{|c|}{ Part 1: The concept of feedback } \\
\hline & Statements & Yes & No & Note \\
\hline 1 & $\begin{array}{l}\text { Students have clear reasons for } \\
\text { writing }\end{array}$ & Yes & & $\begin{array}{l}\text { The teacher presented clear picture of } \\
\text { course introduction, regulation, } \\
\text { course objective and the products of } \\
\text { writing course }\end{array}$ \\
\hline 2 & $\begin{array}{l}\text { Students have opportunity to write } \\
\text { their ideas and discuss/ share with } \\
\text { their classmates }\end{array}$ & & No & $\begin{array}{l}\text { The students were assigned to write } \\
\text { about the local content such as the } \\
\text { traditional foods from their village } \\
\text { origin. They had no chance to choose } \\
\text { their interest topic and share their } \\
\text { ideas because there was no discussion } \\
\text { session available. }\end{array}$ \\
\hline 3 & $\begin{array}{l}\text { Students show their understanding } \\
\text { about the role of peer feedback in } \\
\text { writing classroom activity }\end{array}$ & & No & $\begin{array}{l}\text { The students did not understand the } \\
\text { role of peer feedback in general and } \\
\text { thought that it was a part of their task } \\
\text { writing. }\end{array}$ \\
\hline
\end{tabular}




\begin{tabular}{|c|c|c|c|c|}
\hline 4 & $\begin{array}{l}\text { Students understand the way to give } \\
\text { constructive and meaningful } \\
\text { feedback }\end{array}$ & & No & $\begin{array}{l}\text { The students did not how to provide } \\
\text { constructive and meaningful } \\
\text { feedback and it was shown through } \\
\text { the content of feedback focused on } \\
\text { grammatical errors, punctuation, and } \\
\text { word choice. }\end{array}$ \\
\hline \multicolumn{5}{|c|}{ Part 2: The procedure of peer feedback } \\
\hline 1 & $\begin{array}{l}\text { Students are trained to figure } \\
\text { out the purpose of their review }\end{array}$ & Yes & & $\begin{array}{l}\text { The students were trained not by the } \\
\text { teacher, but by the researcher, and it } \\
\text { was a very short practice. }\end{array}$ \\
\hline 2 & $\begin{array}{l}\text { Students have chances to } \\
\text { chose / select one of the } \\
\text { classmates as a reviewer }\end{array}$ & Yes & & $\begin{array}{l}\text { The students were free to choose } \\
\text { their peers and particularly they } \\
\text { tended to choose their close friend } \\
\text { They had } 30 \text { minutes to read their } \\
\text { peer's writing and provided feedback. }\end{array}$ \\
\hline 3 & $\begin{array}{l}\text { Students are facilitated with } \\
\text { criteria, rubric, principles and } \\
\text { guidelines for reviewing } \\
\text { peer's writing }\end{array}$ & Yes & & $\begin{array}{l}\text { The students were facilitated with } \\
\text { criteria, rubric, principles, and } \\
\text { guidelines for reviewing their peer's } \\
\text { writing and it was provided by the } \\
\text { researchers because it was instructed } \\
\text { by the classroom teacher. }\end{array}$ \\
\hline 4 & $\begin{array}{l}\text { Students work on peer based } \\
\text { on the time allocation }\end{array}$ & Yes & & $\begin{array}{l}\text { The students had } 30 \text { minutes to read } \\
\text { their peer's writing and provided } \\
\text { feedback. It was done only once. }\end{array}$ \\
\hline 5 & $\begin{array}{l}\text { Students have chance to study } \\
\text { their peer's comments deeply }\end{array}$ & Yes & & $\begin{array}{l}\text { The students reflected their writing } \\
\text { from the peer feedback and revised it. }\end{array}$ \\
\hline \multicolumn{5}{|c|}{ Part 3: Teacher's role in peer feedback } \\
\hline 1 & $\begin{array}{l}\text { Teacher gives clear example of } \\
\text { How to give peer feedback }\end{array}$ & Yes & & $\begin{array}{l}\text { The researchers provided brief } \\
\text { explanation about the ways of giving } \\
\text { peer feedback in writing projects }\end{array}$ \\
\hline 2 & $\begin{array}{l}\text { Teacher trains the students in } \\
\text { providing feedback }\end{array}$ & & No & $\begin{array}{l}\text { The teacher did not train the } \\
\text { students, and the charge was given } \\
\text { for the researchers. }\end{array}$ \\
\hline
\end{tabular}


Teacher helps the students in

3 clarifying things after the students got feedback from their peer
The teacher only instructed the students to develop their writing based on the comments and suggestion provided by their peers.

Table 2. Writing 4 course

\begin{tabular}{|c|c|c|c|c|}
\hline \multicolumn{5}{|c|}{ Part $1:$ The concept of feedback } \\
\hline & Statements & Yes & No & Note \\
\hline 1 & $\begin{array}{l}\text { Students have clear reasons } \\
\text { for writing }\end{array}$ & Yes & & $\begin{array}{l}\text { The teacher presented clear } \\
\text { picture of course introduction, } \\
\text { regulation, course objective and } \\
\text { the products of writing course }\end{array}$ \\
\hline 2 & $\begin{array}{l}\text { Students have opportunity to } \\
\text { write their ideas and discuss/ } \\
\text { share with their classmates }\end{array}$ & Yes & & $\begin{array}{l}\text { The students were grouped into } \\
\text { groups to brainstorming the } \\
\text { ideas. }\end{array}$ \\
\hline 3 & $\begin{array}{l}\text { Students show them } \\
\text { understanding about the role of } \\
\text { peer feedback in writing } \\
\text { classroom activity }\end{array}$ & & No & $\begin{array}{l}\text { The students had no idea about } \\
\text { peer review process as well as } \\
\text { They did not have a clear picture } \\
\text { about the aim and benefit of the } \\
\text { peer feedback }\end{array}$ \\
\hline 4 & $\begin{array}{l}\text { Students understand the way } \\
\text { to give constructive and meaningful } \\
\text { feedback }\end{array}$ & & No & $\begin{array}{l}\text { Most of the students did not } \\
\text { know how to give constructive } \\
\text { and meaningful feedback. The } \\
\text { students who had better } \\
\text { academic achievement tend to } \\
\text { give more useful comments and } \\
\text { suggestion to their peers' work }\end{array}$ \\
\hline \multicolumn{5}{|c|}{ Part 2: The procedure of peer feedback } \\
\hline 1 & $\begin{array}{l}\text { Students are trained to figure } \\
\text { out the purpose of their review }\end{array}$ & & No & $\begin{array}{l}\text { The students were not trained } \\
\text { with peer writing because the } \\
\text { teacher assumed that they have } \\
\text { reached the top of the writing } \\
\text { course }\end{array}$ \\
\hline
\end{tabular}




\begin{tabular}{|c|c|c|c|c|}
\hline 2 & $\begin{array}{l}\text { Students have chances to } \\
\text { chose / select one of the } \\
\text { classmates as reviewer }\end{array}$ & & No & $\begin{array}{l}\text { The students were assigned into } \\
\text { groups and they exchanged their } \\
\text { work in form of peer review. }\end{array}$ \\
\hline 3 & $\begin{array}{l}\text { Students are facilitated with } \\
\text { criteria, rubric, principles and } \\
\text { guidelines for reviewing the } \\
\text { peer's writing }\end{array}$ & & No & $\begin{array}{l}\text { There were no rubric forms to } \\
\text { guide students in giving peer } \\
\text { feedback. }\end{array}$ \\
\hline 4 & $\begin{array}{l}\text { Students work on peer based } \\
\text { on the time allocation }\end{array}$ & Yes & & $\begin{array}{l}\text { The students had } 30 \text { minutes to } \\
\text { read their peer's work. }\end{array}$ \\
\hline 5 & $\begin{array}{l}\text { Students have chance to study } \\
\text { their peer's comments deeply }\end{array}$ & & No & $\begin{array}{l}\text { The students had very limited } \\
\text { time in doing peer review } \\
\text { process. }\end{array}$ \\
\hline \multicolumn{5}{|c|}{ Part 3: Teacher's role in peer feedback } \\
\hline 1 & $\begin{array}{l}\text { Teacher gives clear example of } \\
\text { How to give peer feedback }\end{array}$ & & No & $\begin{array}{l}\text { The teacher did not provide } \\
\text { examples of doing peer review as } \\
\text { well providing good example of } \\
\text { peer feedback. }\end{array}$ \\
\hline 2 & $\begin{array}{l}\text { Teacher trains the students in } \\
\text { providing feedback }\end{array}$ & & No & $\begin{array}{l}\text { The teacher did not train the } \\
\text { students in providing feedback. }\end{array}$ \\
\hline 3 & $\begin{array}{l}\text { Teacher helps the students in } \\
\text { clarifying things after the students } \\
\text { got feedback from their peer }\end{array}$ & & No & $\begin{array}{l}\text { There was no oral feedback or } \\
\text { confirmation from the teacher to } \\
\text { help students understand about } \\
\text { their peer's feedback }\end{array}$ \\
\hline
\end{tabular}

\section{In-depth Interview}

There were four students who were involved in in-depth interview section and they represented both courses. Guided questions were provided and it consisted of 3 sections; 1) The student's general views of peer feedback, 2) The student's role as the person who provides feedback and, 3) The student's role as the receiver of peer feedback. The students' answers were varied due to the different backgrounds of the learning achievement level, writing proficiency, and also the treatment in the writing courses. 


\section{Students General View on peer feedback}

Asking about the students' general concepts of peer feedback, from 4 selected students 3 students tend to have negative perspective by stating that they don't really like correcting or giving feedback for their peers' writing because it is not easy to do it. There were some reasons behind the answers, like writing is not an easy task to do. Only student 4 said that he liked to do peer feedback because it can increase his knowledge. When it dealt with the significance of peer feedback the students have different ideas, two students argued that by giving feedback, they can learn from their mistakes and it is useful to improve their writing while the rest students stated that sometimes they didn't have good comments from their peers so it is not helpful for them, as it is shown below;

'It can improve if we get many good feedbacks but if we don't get good feedback. from our peer it will not helpful at all" (Student 3)

When it is related to the content of feedback of writing, and their comments for having feedback from their classmate, the students provided vary responds as it is presented below;

'It's like punctuation and spelling also they asked me to add more references without giving me clue. They always like just make circle and put big X mark on my writing and never confirmed what they mean by giving it" (student 2)

"What I mean by a good peer is, the person who got good skill in learning and their English ability is better too" (Student 1)

"Yeah, because my friend did a very good job in providing feedback for my writing also because I learn many things from these feedbacks. My content and organization was improved a lot. I can add more things in my writing based on feedback from my peer" (Student 4)

Relating to the same level of the importance of peer feedback compared to the teacher feedback, they argued that they did not rely very much on peer feedback and they put high concern on teacher feedback because the teacher is more masterful in giving correct feedback. They also responded that they didn't depend on their peer's feedback, because most of the time, they only focused on grammatical errors as it was presented follows:

'I would not say that it's not important about peer feedback, but I think that I more prefer for feedback. from teacher. We as students we still have to learn, but teachers they already know what 
actually the content is and how we should organize the idea, so like I said before, I don't rely that much on peer feedback" (Student 1)

'I guess, teacher's feedback is the best because they are the one who assess our writing and also, they know the criteria of a good writing should be, meanwhile, peer feedback is about grammatical errors whole this time" (Student 2)

In contrary, student 4 always had positive peer feedback. He implied that everyone could give feedback, whether it was good or bad, he/she could find the best for learning process, as it was presented below;

'Because I think good source of learning can come from any person, not just from teacher, but students can also make a good feedback. So basically, everyone can give feedback weather it's really good or it just not really good, we can still learn from that" (student 4)

\section{The Students' Opinion in Giving Feedback}

Due to their confidence in giving feedback, most students stated that they were not enough confident because they unsure about their own feedback to improve their friends' writing. Besides that, students' anxiety also influenced their performance in giving feedback as it is seen from one of the students answer below:

'Yes, because I think I don't have capability and I' am lack of knowledge and I am afraid to suggest something that are not really useful to my partner" (Student 3)

Differently from the other students, student 4 was believe that he could provide good feedbacks because he knew his capability as follows:

"I think because I know my capability that I can provide good feedback for my peer. I believe that my grammar is good and I have lots of knowledge that can help me to give feedback." (Student 4)

When it was asked about the importance of rubric, guidelines and principles in doing peer review, the students (student 1 and 2) responded that the teacher did not facilitate them with the specific rubric, guidelines questions or some principles in doing peer review. The teacher just instructed them to find out the grammar errors and less to guide them to analyze the organization of writings. On the contrary with student 3 and 4 who enrolled in writing 2 course; they stated they were facilitated with a specific rubric, guidelines questions and principles in doing peer review. The rubric consisted of some elements of writing, framework, wording language, organization, 
content, grammar. Whereas, the guidelines contained some questions to assist them such as, the part that they liked from their peer's writing, the confusing things and suggestions for better improvement. As for the principles, it was related to the policy and the language used in giving comments, the proper suggestion, avoiding bias and less clue.

In terms of the difficulties, problems or challenges that faced by the students in providing peer feedback, they had various answers such incapability in explaining clear concepts of writing, and less provided compatible comments and suggestions:

"One real problem that I always encountered when I provide feedback for my peer, is when he cannot explain that sentence, such as lack of explanation, and when he isn't able to explain that part, I will skip it” (Student 1)

It was also related to the content of peer feedback that were mostly focused on grammatical errors and disorganize ideas, and as resulted it was difficult to understand the writing itself and it was supported with unavailability of rubric and guidelines:

'The problems that I faced, mostly from my peer's work, like many grammar errors and many incoherence sentences one to another, and also myself confident, because I'm not really sure that the feedback will be very useful. Lastly I need real rubric or guidelines to help me provide feedback" (Student 2)

\section{Students opinion in receiving Feedback}

In similar with giving feedback, the students still have constraints with their confidence when they gave feedback. Some students stated that they were not confident of their peer's feedback and others said they it was depend on who gave the feedback, as it was shown below;

"Well, I only confident when that person has high, learning achievement, but if someone with low learning achievement, I don't really like have that much expectation about their feedback. "(Student 1)

"Okay, if the person who provides feedback is a person who is smart enough, I'm kind of little bit confident to use their feedback. But if it comes from a person who doesn't really smart, I think I don't really trust their feedback" (Student 2)

On the other side, student 4 claimed that he is believe and confident, his peer could give good feedbacks: 
"Yes, I really confident, because before I chose him, I have already known his skill and his knowledge, so I kind of agree if I myself chose my own peer" (Student 4)

But, when it was to the personal preferences about who was the person they would likely choose to ask feedback from, all students had the similar responds that they preferred to have feedback from a student who a good learning achievement and have better English proficiency.

"Well, I think because someone who smart, they are more expert in giving opinion and suggestion and they have more knowledge" (Student 3)

Furthermore, these students also asked clarification after receiving feedback and they thought it was very important to have clear picture about it. There was no such oral feedback to support their writing peer feedback, and as the result they tried to find clarification from the person outside the class:

'If they can't explain for me what actually they mean, I will try to figure it out what it means, but if I still cannot understand, I just ignore it" (Student 1)

'In reality, we don't have something like that in Writing 4, basically, after receiving feedback from ourpeer, the they don't explain what they mean by and let us figure out what is it all about."

(Student 2)

Regarding the question about their expectation for better improvement in peer feedback process in the writing class, the students suggested that the teacher should have more control over the activity, provide examples, rubrics and guidelines and as well as train them to provide feedback as it is shown in the below comments;

"My suggestion is probably the lecturer should provide example of a good feedback and the second one, they must to give opportunity to let students clarify the written feedback so there is no things that left bias" (Student 1)

"Okay, my suggestions are, perbaps, the teacher must put their concern about peer feedback and also control the process. Then, the teacher needs to provide us with the real rubric or at least the guidelines question, so it can belp us to give a good feedback, don't forget about the real example of errors and how to fix it" (Student 2)

"I think the teacher should decide who should be peer to who so it will be balanced and it is better to have only one project, so the process of writing will be meaningful" (Student 3) 


\section{Huele}

Journal of Applied Linguistics, Literature and Culture

\section{Document Review}

As the complementary of the other research instruments and was considered equal, it was also highly needed to study the documents found in writing 4 and writing 2 courses in form of their outline or drafts that contained the feedback from the peer they had and also some supporting documents such as rubric. As the result, most of the students in both classes tend to give peer feedback around grammatical, punctuation and language choice area. They had no clue of what to write for the content and organization of their peer's writing as can be seen below.

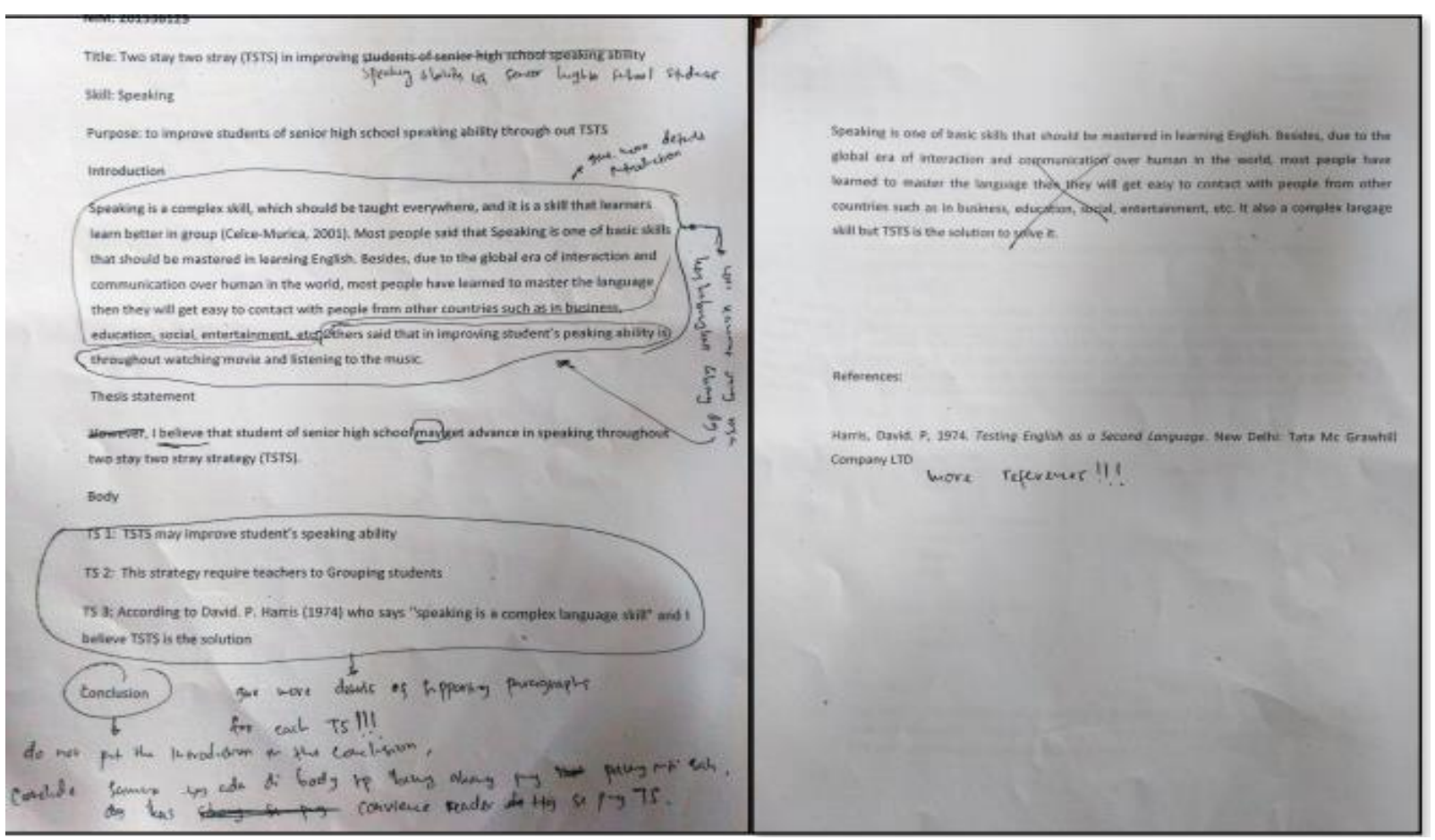

Even though they were supplied with rubrics and guidelines (students of writing 2 course), they still cannot lay out better peer feedback based on the points that available in their guiding papers. This is believed as the lack of gradual training from the teachers causing them to demotivated in providing peer feedback. However, the students with better academic achievement were more incline in give meaningful and constructive feedback, due to their learning experiences and greater amount of knowledge they have, as can be seen below 


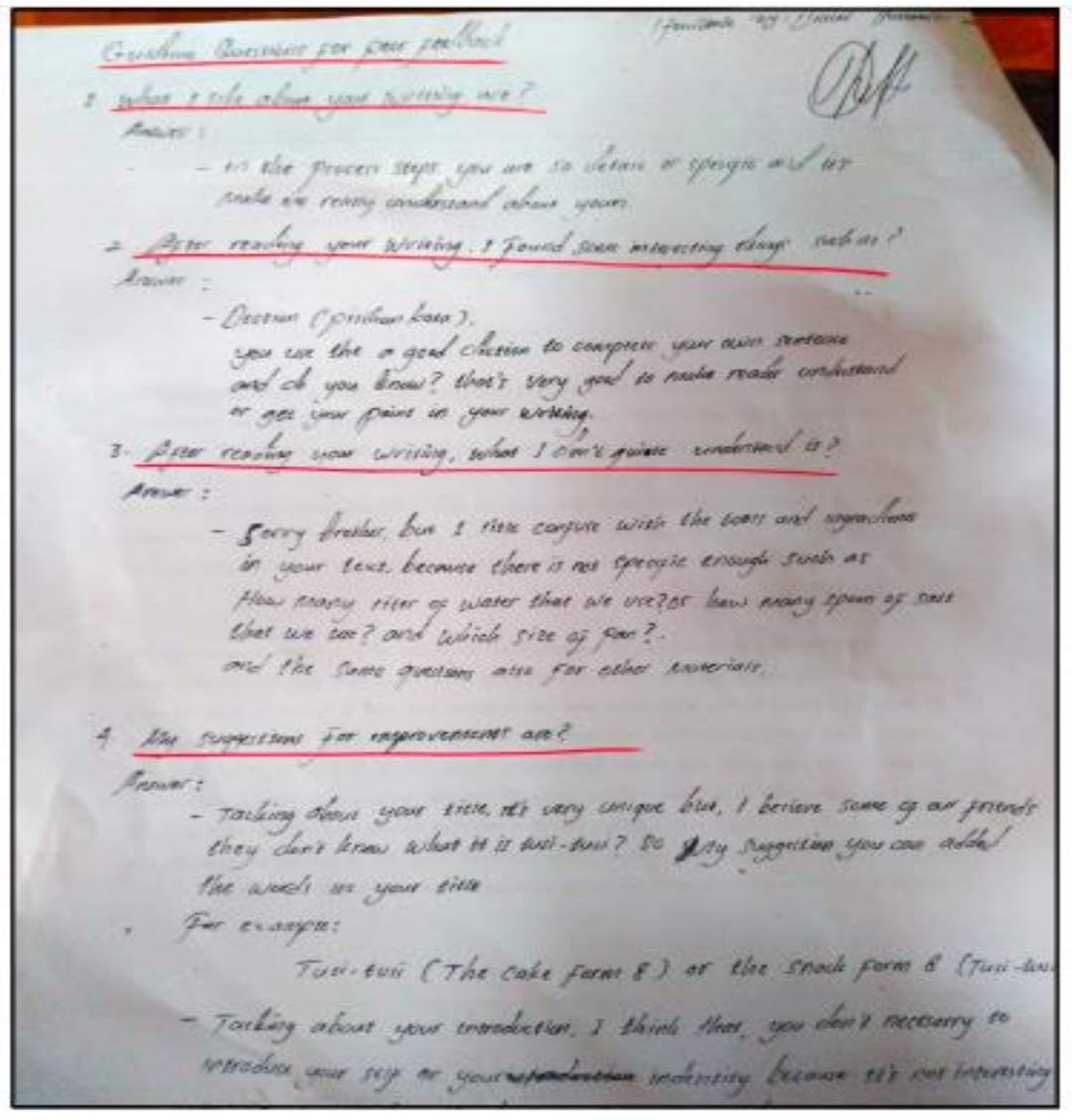

\section{Discussion}

The findings of study revealed that almost all students have negative point of view of peer feedback. They preferred to have feedback from the teacher than their own classmates because they assumed that the teacher is a qualified person in providing meaningful comments. In line with this idea, Kagni (2015) described that in students' point of view, a teacher is portrayed as the resourceful person based on his professional knowledge and teaching experiences in this writing skill, therefore he is capable in providing constructive feedback.

On the other hand, some students were addressed to providing feedback for their peers and they have positive view on it even though they knew that the assessment is a part of teacher' works. (Pearce, Mulder \& Baik, 2009). In addition, Tsui and Ng (as cited in Gielen et al, 2010) mentioned that the feedback from teacher was more absorbed in students' revision than the feedback from peers because students perceived teacher comments as more useful, but the impact of comments on the quality of final assignments was not examined. For that reason, the students being doubt of their ability that they cannot replace the teacher feedback. Some students revealed that they were afraid when they have to provide feedback for their peers, because incapability in giving good comments and critics for their peer's work. Hansson (2015) explained that sometimes 


\section{Huele}

Journal of Applied Linguistics,

Literature and Culture

students felt uneasy when they provided negative comments for their peers and as result it was impact for the friendship bias. As an addition, Harris, and Brown (as cited in Hanson, 2015) stated that "the students value teacher response higher than peer response, they did not trust their own ability to make accurate judgments". At the same time the student skeptical about their peer's competence in providing feedback particularly for those who have lower competence in that skill, they would not bank on feedback from peers.

The students in writing class believe and prefer to ask feedback from the students who have a high level of learning achievement and a good level of English proficiency rather than the students who have low learning achievement. Rolinson (2005) stated that "many students may need a significant amount of initial persuasion of the value of peer feedback, since they may not easily accept the idea that their peers are qualified to act as substitutes for the teacher and critique their writing". That is why students need to know what they are expected to learn from exchanging feedback with their peers.

The quality of peer feedback can be done through training students to use specific criteria, that presented samples of good writing feedback when commenting on their peer's writing, (Gielen et al., 2010). Facts of the writing class showed that some students have trainings and guidelines of peer review while others didn't have trained and guidelines. It is recommended to have adequate trainings which were supported with transparent and useful procedures in order to make the practice of peer feedback more effective in the future. It is also important for establishing guiding questions, checklist and rating scales as it is pointed by McGill University (2017) that teacher must develop questions that ask the students to focus on the element of the assignment. The question may ask students to summarize the piece of writing or identify specific elements of the assignment, rather than make a judgment about the quality of the writing. Providing rubric is also very crucial to help students provide meaningful feedback so they can avoid providing feedback on surface or micro areas. The last important thing is checklist and rating scales which are designed based on specified criteria with a range selection to describe the quality of student writing work.

Almost all the students giving feedback merely on surface level errors (grammatical, punctuation, spelling, etc.), and it is in line with the study conducted by McGoarty and Zhu (As cited in Hyland \& Hyland 2006), who reported that students were over-focused on surface level errors. Moreover, Bartles (2003) claimed that this thing happened because students are untrained to give feedback so they will focus on the things that don't really matter and will likely forget about the content and text organization as well as the language choices. 
The result of interview revealed that grammar error correction is the last thing that they could do to help their peer in their revision and they realized sometimes it was not really helpful because they also have limitation in grammar mastery. It is also found that the students would likely avoid giving feedback on the content and text organization as well as the language choices, because they preferred the teacher to handle those aspects of writing, because they assumed that the teacher can provide feedback on that area so they don't have to struggle in giving feedback on that areas.

From their experiences in giving and taking feedback from their peers, the students expected that the content of peer feedback is not only focused on grammar errors but also it should cover the content and text organization, and hoped that the teacher still have full control in peer feedback procedures starting from selecting a peer, providing tools that needed such as rubric and guidelines as well as train them to provide feedback based on the real example.

\section{Conclusion}

The facts of peer feedback in writing 2 and writing 4 courses as follows;1) The students agree that the peer feedback is not really important in contrast to the teacher's feedback and still value the teacher's feedback as the way to improve the quality of their writing. 2) The process of peer review was not optimal in writing 4 course compared to writing 2 course because the students have not experienced in peer review procedures; they didn't understand the ways to give meaningful feedback and they didn't provide with some rubrics and guidelines as well as unsupported with oral feedback given by their peers. 3) Most feedback related to grammatical error, punctuation and spelling and less to touch content of writing itself. Based on the facts above, the students expected that the implementation of peer feedback in writing courses shouldn't be focused just in grammatical errors, but it should beyond to content and organization of the writing, so that their writing will be improved.

\section{References}

Bartels, N. (2003). Written peer response in L2 writing. English Teaching Forum, 41 (4)..

Cooper, D., Barton, M., \& The RP Group. (2009). Classroom-based research: How to be a researcher in your classroom. Retrieved from: https://slideplayer.com

Elashri, I. (2013). The impact of the direct teacher feedback strategy on the EFL secondary stage students' writing performance. retrieved from $: \underline{\text { https://files.eric.ed.gov }}$ 
Gielen, S., Peeters, E., Dochy, P., Onghena, P., Sturyven, K. (2010). Improving the effectiveness of peer feedback for learning. Learning and Instruction. 20.

Hansson, S. (2015). Benefits and difficulties in using peer response for writing in the EFL classroom.

Retrieved

from:

https://gupea.ub.gu.se/bitstream/2077/38436/1/gupea 207738436 1. pdf

Hyland, K. (2004). Second language writing. Cambridge: Cambridge University Press.

Hyland, K. \& Hyland, F. (2006). Feedback in second language writing: Contexts and issues. New York: Cambridge University Press.

Iryanti, D. (2015). The effectiveness of peer feedback in improving students' writing achievement. Retrieved from: http://repository.uinjkt.ac.id

Kagni, W. (2015). Problems and tactics in peer feedback in EFL writing teaching. Paper published in the Second International Conference on Education, Management, and technology (ICEMIT)

McGill Univercity. (2017). Peer assessment resource document. Teaching and Learning service. Quebec, Canada (Retrieved from : https://www.mcgill.ca/tls/files/tls/pa-resource-docfinal.pdf

Pearce, J,Mulder, R,. \& Baik, C. (2009). Involving students in peer review: A case study and $\begin{array}{llll}\text { practical strategies for university teaching. } & \text {. }\end{array}$ https://www.academia.edu/971160/Involving students in peer review Case stu diesand practical strategies for university teaching

Riyani, . (2009). Improving the students' writing skill through feedback: Retrieved from : https://digilib.uns.ac.id/

Rolinson, P. (2005). Using peer feedback in the efl writing class. ELT Journal Volume. 59. Retrieved from http://citeseerx.ist.psu.edu/viewdoc/

Wakabayashi, R. (2008). The effect of peer feedback on efl writing: focusing on Japanese university students. Oncue Journal. 2(2). 92-110. 